\title{
DEMAND FOR FIBERBOARD PANELS IN THE INTERNATIONAL MARKET
}

\author{
Antonio Donizette de Oliveira ${ }^{1}$, Francisco Fernandes Bernardes ${ }^{2}$, José Luiz Pereira de Rezende ${ }^{3}$, \\ José Márcio de Mello ${ }^{4}$, José Roberto Soares Scolforo ${ }^{5}$, Luiz Moreira Coelho Junior ${ }^{6}$
}

(received: February 12, 2010; accepted: September 27, 2010)

\begin{abstract}
The objective of this study is to estimate for several importing countries of fiberboard panels the income elasticities and price elasticities of total import demand and also the own-price and cross-price elasticities of demand for fiberboard panels, differentiated by country of origin. Time series data were used referring to the trade flow of the world's largest exporters and importers of fiberboard panels. The demand model being used treats products as imperfect substitutes. It was concluded that in Germany, China and United Kingdom the total import demand for fiberboard panels was more sensitive to variations in price than in income, whereas in other importing countries the reverse happened. The own-price elasticity of demand for fiberboard panels, differentiated by country of origin, was higher than one in almost all markets, except in Germany and United Kingdom. The negative cross-price elasticities suggest that fiberboard panels imported from other exporting countries are complementary products.
\end{abstract}

Key words: Armington model, forest products trade, export, import.

\section{DEMANDA DE PAINÉIS DE FIBRA DE MADEIRA NO MERCADO INTERNACIONAL}

RESUMO: Objetivou-se, neste estudo, estimar, para os diversos países importadores de painéis de fibra de madeira, as elasticidadesrenda e as elasticidades-preço da demanda total de importação e as elasticidades-preço diretas e cruzadas da demanda por painéis de fibra de madeira, diferenciados por país de origem. Utilizaram-se dados de séries temporais referentes aos fluxos comerciais dos maiores exportadores e importadores mundiais de painéis de fibra de madeira. O modelo de demanda utilizado considera que os produtos não são substitutos perfeitos. Concluiu-se que na Alemanha, na China e no Reino Unido, a demanda total de importação de painéis de fibra de madeira foi mais sensível às variações no preço que na renda, enquanto nos outros países importadores ocorreu o contrário. A elasticidade-preço direta da demanda por painéis de fibra de madeira, diferenciada por país de origem, foi maior que um em quase todos os mercados, com exceção da Alemanha e do Reino Unido. O valor negativo das elasticidades-preço cruzadas sugere que os painéis de fibra de madeira importados dos outros países exportadores são produtos complementares.

Palavras-chave: Modelo de Armington, comércio de produtos florestais, exportação, importação.

\section{INTRODUCTION}

Fiberboard panels are characterized as being highly homogeneous and isotropic structures, the manufacturing process being responsible for conferring advantages in terms of homogeneity of properties. Several types of wood fiberboard panels are available which can be grouped into laminate composites and particulate composites. The first group comprises plywood and blockboard, whereas the second group comprises mineral board (flake and excelsior), fiberboard (hardboard, medium density fiberboard or MDF, and insulating board) and particleboard (conventional, waferboard, and oriented strand board or OSB).

In 2007 , the worldwide production of fiberboard panels was 72.4 million cubic meters. The largest producer was China, accounting for $37.76 \%$ of the total. In the global market, the largest exporters are China, Germany, Canada, Thailand, Malaysia and Poland. Together, they account for about $50.76 \%$ of the international trade of the product. United States, China, Italy, United Kingdom, France and Canada are the largest buyers, importing about $38 \%$ of the total marketed (FOOD AND AGRICULTURE ORGANIZATION - FAO, 2008).

\footnotetext{
${ }^{1}$ Forest Engineer, Professor, Dr. in Forest Science - Departamento de Ciências Florestais - Universidade Federal de Lavras - Cx. P. 3037 - $37200-000$ Lavras, MG, Brasil - donizete@dcf.ufla.br

${ }^{2}$ Forest Engineer, MSc in Forest Engineering - Vallourec e Mannesmann Florestal Ltda - Rua Honduras n 78, Léo Batista - 35790-000 - Curvelo, MG, Brasil

${ }^{3}$ Forest Engineer, PhD in Forest Economy - Departamento de Ciências Florestais/DCF - Universidade Federal de Lavras/UFLA - Cx. P. 3037 37200-000 - Lavras, MG, Brasil -jlprezen@dcf.ufla.br

${ }^{4}$ Forest Engineer, Professor, Dr. in Forest Resources - Departamento de Ciências Florestais - Universidade Federal de Lavras - Cx. P. 3037 - 37200-000 Lavras, MG, Brasil - josemarcio@dcf.ufla.br

${ }^{5}$ Forest Engineer, Professor, Dr. in Forest Engineering - Departamento de Ciências Florestais - Universidade Federal de Lavras - Cx. P. 3037 37200-000 - Lavras, MG, Brasil - jscolforo@dcf.ufla.br

${ }^{6}$ Economist, Researcher in socioeconomics - Intituto Agronômico do Paraná (IAPAR) - Rodovia BR 163, Km 188 - 85825-000 - Santa Tereza do Oeste, PR, Brasil-1mcjunior@hotmail.com
}

Cerne, Lavras, v. 17, n. 1, p. 33-45, jan./mar. 2011 
The use of economic models for analysis in the forest sector is recent and highly elaborate as far as methods and applications are concerned (RIBEIRO, 2003). According to Grennes et al. (1979), what differentiates one model from another are the restrictions associated to them, whether related to the economic theory or to the functional specification of the model.

The development of models in the forest sector is due to a large extent to the evolution of agriculture, having included representations of supply and demand, spatial treatment of production and consumption, as well as distinction between resource and product markets. Several types of models can be used to study international trade patters, with special mention of market share models, economic equilibrium spatial models, and differentiated product models or Armington models (RIBEIRO, 2003).

As far as trade of agricultural products is concerned, several examples can be given of the application of the Armington model, including the works of Abbott and Paarlberg (1986), Babula (1987), Figueroa and Webb (1986), Grennes et al. (1979), Johnson et al. (1979), Penson and Babula (1988), and Sarris (1983) and Silva (1990, 1993). As for the trade of forest products, however, the Armington theory has been little used so far and includes the works of Chou and Buongiorno (1983), Cruz (2001), Oliveira et al. (1996) and Ribeiro (2003). In the first case, the study consisted of estimating United States demand for hardwood plywood, imported from Korea, Taiwan, Japan, Philippines, and other countries grouped into a region referred to as 'rest of the world'. Plywood differentiation by country of origin allowed estimating, for each exporting country, own-price and cross-price elasticities of demand for the product imported by the United States. In the second case, the authors assessed the evolution of prices and flow of cellulose pulp in the international market, considering the main exporting and importing countries. To achieve that, they formulated a model of the international cellulose pulp trade to simulate sudden changes in exogenous variables, including changes in supply and demand shifters and tariffs imposed on imports. Cruz (2001) studied cellulose pulp and paper trade, and Ribeiro (2003) studied plywood trade.

Oliveira et al. (1996) argue that knowing the imports demand structure is important for all countries involved in the international market of a given product. This empirical information about elasticities of demand can help exporting countries in defining price policies and planning production. Questions involving changes in the participation of a given importer in a specific market due to an increase in its sale price or in the sale price of competitor countries can be better answered with knowledge of equations of import demand differentiating products by country of origin.

According to Barros (1987), econometric analysis is becoming increasingly critical in modern day economy, given the need to access market responsiveness in both the short and long term to various changes that are imposed in a multitude of ways. Assessing the likely consequences of policies being adopted is critical, prior to them being adopted.

This work aims to estimate, for various importing countries of fiberboard panels, the income elasticities and price elasticities of total import demand for the product, as well as and the own-price and cross-price elasticities of demand for fiberboard panels, differentiated by country of origin.

\section{MATERIAL AND METHODS}

In order to analyze the import demand for fiberboard panels differentiated by country of origin, the Armington elasticity model (1969a,b) was used. This model treats products as imperfect substitutes, that is, if the price of one is lower than the price of the rest, it does not mean that the importing country will stop buying higher priced products, for the fact that the importer needs that particular product exclusively, with no substitution for another from a different origin being possible.

The estimation of demand equations was obtained using a two-stage maximization process. In the first stage, the total utility of a given country was maximized through the allocation of total spending $(E)$, in the quantities demanded of each type of good $\left(X_{i}\right)$. One of such goods is fiberboard panel, and fiberboard panels from different origins $\left(X_{i j}\right)$ are considered differentiated 'products'. The price of each good $\left(P_{i}\right)$ is represented by a product price function $\left(P_{i j}\right)$, in market i. In the second stage, the importing country allocates its purchases so as to maximize spending $\left(E_{i}\right)$ in each predetermined quantity of $X_{i}$. The two processes are summarized as follows:

$$
\begin{aligned}
& \operatorname{Max} U=U\left(X_{i}, \ldots, X_{m}\right) \quad \text { subject to } E=\sum_{i=1}^{n} X_{i} P_{i} \\
& \Rightarrow X_{i}=X_{i}\left(E, P_{i}, \ldots, P_{n}\right) \\
& \operatorname{Min} \sum_{i=1}^{m} P_{i j} X_{j} \quad \text { subject to } X_{i}=\theta\left(X_{i 1}, \ldots, X_{i m}\right. \\
& \Rightarrow X_{i j}=X_{j}\left(X_{i}, \frac{P_{j}}{P_{i 1}}, \ldots, \frac{P_{j}}{P_{i}}\right)
\end{aligned}
$$

Cerne, Lavras, v. 17, n. 1, p. 33-45, jan./mar. 2011 
By grouping (1) and (2), the following is derived:

$X_{i j}=X_{j}\left(E, P_{1}, \ldots, P_{n}, \frac{P_{j}}{P_{i 1}}, \ldots, \frac{P_{j}}{P_{i n}}\right)$

where $n$ represents the number of goods, and $m$ represents the number of products in each market.

If a single maximization process was used, $n \times m$ prices would be required, while, if two stages were used, only $n+m$ prices would be required. However, this simplification is at a cost. Two-stage maximization presupposes weak separability of utility function and degree of priority, for deriving demand equations in equation (2)

Weak separability implies that the marginal rate of substitution between two products competing in the same market of good $i$ is independent of any other goods. This represents a restriction in the preference of the importing country.

The adopted model also assumes that the elasticity of substitution is constant and equal between any product pair, in the same market. Therefore, it considers that the demand for each good $(\mathrm{Xi})$ is a constant elasticity of substitution (CES) function:

$X_{i}=\left[b_{i 1} X_{i 1}^{-\rho_{i}}+\ldots+b_{i m} X_{i m}^{-\rho_{i}}\right]^{-\frac{1}{\rho_{i}}}$

From (4), equations of import demand for products (fiberboard panels) have the following form:

$X_{i j}=b_{j}^{\sigma_{i}} X_{i}\left(\frac{P_{j}}{P_{i}}\right)^{-\sigma_{i}}$

where $X_{i}$ is the quantity index of fiberboard panels demanded by country $i$; $X_{i j}$ is the quantity of fiberboard panels of country $j$ going into country $i ; P_{i}$ is the price index of fiberboard panels in country $i ; P_{i j}$ is the price of fiberboard panels of country $j$ in country $i ; \sigma_{i}$ is the elasticity of substitution between any pair of fiberboard panels in country $i$; and $b_{i j}$ is the ratio of export value of fiberboard panels of country $j$ that go into country $i$, to the total worldwide export value of fiberboard panels.

By differentiating equation (5), an equation is derived that is expressed by percentage changes:

$$
\begin{aligned}
& d \ln X_{i j}=\varepsilon_{i} d \ln \mathrm{E}-\left[\left(1-S_{i j}\right) \sigma_{i}+S_{i j} \eta_{i}\right] d \ln P_{i j}+\sum_{h=j}\left[S_{i h} \sigma_{i}-\right. \\
& \left.S_{i h} \eta_{i}\right] d \ln P_{h}+\sum_{h=1} \eta_{i h} d \ln P_{h}
\end{aligned}
$$

where

$\varepsilon_{\mathrm{i}}=$ income elasticity of $X_{i j}$;

- $\left[\left(1-S_{i j}\right) \sigma_{i}+S_{i j} \eta_{i}\right]=\eta_{\mathrm{ijj}}$ is the own-price elasticity of demand for fiberboard panels of country $j$ in country $i$; $\left[S_{i h} \sigma_{i}-S_{i h} \eta_{i}\right]=\eta_{\mathrm{ijh}}$ is the cross-price elasticity of demand for fiberboard panels of country $j$, with respect to the price of fiberboard panels of country $h$, in country;

$\eta_{i}=$ price elasticity of total import demand for fiberboard panels in country $i$;

$\eta_{i h}=$ cross-price elasticity of demand for fiberboard panels of country $j$ in country $i$, with respect to price of products from other groups;

$S_{i j}=$ share of country $j$ in imports of $\operatorname{good} X_{i}$ in country $i$, that is, relative participation in spendings with fiberboard panels of country $j$ in country $i$.

The number of parameters forming own-price and cross-price elasticities of import demand is small. To obtain $S_{i j}$ values, data were used on the worldwide trade flow of fiberboard panels. $\eta_{i}$ values were estimated using a fiberboard panel import demand function, at the aggregate level, fitted to each importing country with no reference to the origin. In the first stage, when total utility has to be maximized, the importing country decides on the quantity of fiberboard panels to buy based on price of fiberboard panels, on prices of competitive goods, on the level of income and on other country-specific variables. However, according to model assumptions, prices and quantities in this stage should be such that the demand for fiberboard panels is consistent with the optimal selection of products in each market. Thus, in order to estimate the total import demand for fiberboard panels, one should use quantity and price indices based on the elasticities of substitution estimated in the second stage. Assumptions of the Armington model allow specifying such indices as being constant elasticity of substitution functions (CES indices), whose formulas are expressed as:

$X_{i}=\left[\sum_{j=1}^{m} b_{j}\left(X_{j}\right)^{-\rho_{i}}\right]^{-\frac{1}{\rho_{i}}}$
$P_{i}=\left[\sum_{j=1}^{m}\left(b_{j}\right)\left(P_{j}\right)^{1-\sigma_{i}}\right]^{\frac{1}{1-\sigma_{i}}}$

where

$\sigma_{i}=\frac{1}{\left(1+\rho_{i}\right)} ;$

$X_{i}=$ CES quantity index of fiberboard panels in country $i$;

$P_{i}=$ CES price index of fiberboard panels in country $i$.

Cerne, Lavras, v. 17, n. 1, p. 33-45, jan./mar. 2011 
The per capita Gross Domestic Product (GDP) was used as an indicator of income in each importing country, while the effect of prices of competitive goods was implicitly obtained by using real prices and GDP. The model of total import demand for fiberboard panels can be expressed as:

$$
\left(X_{i}\right)_{t}=\beta_{0} P_{i}^{\beta_{1}} Y_{i}^{\beta_{2}}\left(X_{i}\right)_{t-1}^{\beta_{3}}
$$

where $Y_{i}$ represents the per capita GDP and $\left(X_{i}\right)_{t-1}$ is the lagged dependent variable which was introduced in the model on the assumption that there is market rigidity and that fiberboard panel imports in a given year almost always correspond to contracts made in the preceding year.

According to Oliveira (1995), the use of lagged variables in demand studies is commonly found in specialized literature, and authors such as Goldstein and Khan (1976), Khan (1974), Turnovsky (1968), Wilson and Takacs (1979) and Yadav (1975) argue that demand does not adjust instantly to changes in any of the parameters considered for its determination. According to Malinvaud (1970), as cited by Oliveira (1995), one of the justifications for using demand equations including lagged variables is that imports are based on contracts between far-apart countries, which do not respond instantly to changes in demand.

Model (11) was fitted in log-linear form so that price elasticities and income elasticities of total import demand for fiberboard panels are measured directly from the coefficients of variables price index $\left(P_{i}\right)$ and per capita $\operatorname{GDP}\left(Y_{i}\right)$ respectively.

In order to obtain the elasticities of substitution $\left(\sigma_{i}\right)$, a product demand equation was estimated as specified in (5). In order to obtain the constant elasticity of substitution, which is a fundamental assumption of the Armington model, the equation was fitted in log-linear form, expressed as:

$$
\ln \left(X_{i j}\right)=\sigma_{i} \ln \left(b_{i j}\right)+\ln \left(X_{i}\right)-\sigma_{i} \ln \left(P_{i j} / P_{i}\right)+\ln (\varepsilon)
$$

where $X_{i}$ is the total quantity of fiberboard panels consumed by country $i$; and $P_{i}$ is the average price of fiberboard panels in the world market, equal to the average export price of Germany, Austria, Belgium, Brazil, Canada, China, United States, France, Italy, Holland, Norway, Switzerland, Poland, United Kingdom, Russia and Sweden, weighted by the respective ratios of export value of these countries to the international trade.

Cerne, Lavras, v. 17, n. 1, p. 33-45, jan./mar. 2011
According to Ball (1973), these $X i$ and $P i$ values represent well the real CES quantity and price indices, as calculated by formulas (10) and (11) respectively, often being used in estimations of product demand equations, in the Armington model. The work of Cruz (2001) and Oliveira (1995) on international trade of cellulose pulp and paper, and the work of Ribeiro (2003) on international trade of plywood, exemplify the use of $X i$ and $P i$ values in substitution for CES index values.

In order to satisfy the assumption that elasticities of substitution are constant and equal between any product pair, in a given market, the average value of elasticity of substitution was used.

Models were fitted using the ordinary least squares method (OLS). The F test was used to test the statistical significance of regressions, while the adjusted coefficient of determination $\left(\overline{R^{2}}\right)$ was used to assess the degree of equation fitting. Also, the statistical significance of estimated coefficients was verified by Student's t-test.

Tests for the existence of serial autocorrelation of residuals were based on Durbin-Watson's d-statistic and Durbin's h-statistic, the latter being used for models that included a lagged endogenous variable as explanatory variable. The existence of serial correlation in residuals means that parameters are ineffective, despite being unbiased.

Where autocorrelation was detected, the interactive method of Cochrane-Orcutt was used for solving such problem, as presented by Gallant and Goebel (1976).

To study fiberboard panel demand in the international market, the following countries were selected as importers: United States (EUA), China (CH), Germany (AL), Canada (CA), Italy (IT), United Kingdom (RE), France (FR), and Russia (RU), in addition to a region referred to collectively as 'Rest of the World' $\left(\mathrm{RDM}_{1}\right)$ comprising all remaining importers. The following countries were selected as exporters: Austria (AU), Germany (AL), Belgium (BE), Brazil (BR), Canada (CA), China (CH), France (FR), Italy (IT), Holland (HO), Norway (NO), Poland (PO), Russia (RU), Spain (ES), Sweden (SUE), Switzerland (SU), United Kingdom (RE) and United States (EUA). The remaining exporters were grouped into a region referred collectively as 'Rest of the World' $\left(\mathrm{RDM}_{2}\right)$.

Although Thailand, Malaysia, Turkey and New Zealand rank 4th, 5th, 13th and 14th respectively in the list of largest exporters of fiberboard panels, they were not computed individually in the analysis due to data unavailability on the trade flows of these countries covering every year of the 1997 2006 interval, a precondition to apply the Armington model. 
Data on trade flows (value in US\$ and quantity in $\mathrm{m}^{3}$ of fiberboard panels that each exporter sells annually to each importer) refer to annual time series covering the 1997-2006 interval and were retrieved from FAO website (2008). Longer time series are unavailable in the website for the relevant period and no other source was accessible in the format required by the Armington model.

\section{RESULTS AND DISCUSSIONS}

Table 1 provides elasticities of substitution regarding fiberboard panel imports for model fitting. The low value found indicates low substitutability between fiberboard panels imported by a given country.

The total import demand was estimated using model 11 and results are provided in Table 2. For estimations of CES quantity and price indices (formulas
10 and 11), average values of elasticity of substitution in Table 1 were used. The per capita Gross Domestic Product (GDP)-deflated by the consumer price index of the United States and taking 2005 as base year-was used to represent the level of income.

Price elasticities and income elasticities of total import demand for fiberboard panels are expressed by the coefficients of variables $P i$ and GDP respectively. Model fitting to Canada data showed autocorrelation which was corrected using the Cochrane-Orcutt method.

As for Germany, United States and France, models did not show good statistical fitting, since $\mathrm{R}^{2}$ values were low. Model fitting to China data showed the highest coefficient of determination (0.954), indicating that $95.4 \%$ of variations in total demand for fiberboard panels from China are explained by the independent variables inserted for model fitting.

Table 1 - Elasticities of substitution regarding fiberboard panel imports.

Tabela 1 - Valores das elasticidades de substituição da importação de painéis de fibra de madeira.

\begin{tabular}{|c|c|c|c|c|c|c|c|c|c|}
\hline \multirow{2}{*}{ Exporting countries } & \multicolumn{9}{|c|}{ Importing countries ${ }^{1}$} \\
\hline & $\mathrm{AL}$ & $\mathrm{CA}$ & $\mathrm{CH}$ & EUA & FR & IT & $\mathrm{RE}$ & RU & $\mathrm{RDM}_{1}$ \\
\hline Germany & - & -3.316 & -0.819 & -2.357 & -1.530 & -0.605 & -0.106 & -0.570 & 0.148 \\
\hline Austria & -0.480 & -2.401 & -0.213 & -1.494 & -0.808 & -1.517 & 1.361 & 0.221 & -1.836 \\
\hline Belgium & -0.548 & -2.334 & -0.933 & -0.027 & -1.198 & 0.168 & 0.094 & -0.226 & -1.450 \\
\hline Brazil & -0.012 & -0.226 & 0.836 & -0.170 & -1.109 & -1.564 & -1.736 & -2.275 & -1.520 \\
\hline Canada & -0.982 & - & -0.882 & -0.821 & -0.948 & -0.743 & -1.096 & 0.738 & 0.644 \\
\hline China & 0.172 & -3.176 & - & -0.322 & -0.882 & -0.441 & -2.815 & 2.241 & 4.952 \\
\hline Spain & -3.431 & -1.067 & -1.260 & -0.371 & -0.794 & 0.640 & -1.517 & -0.782 & -0.881 \\
\hline United States & -1.367 & 1.304 & -0.626 & - & -0.210 & -1.263 & -0.534 & 0.971 & 1.562 \\
\hline France & -1.639 & -1.523 & -1.150 & -0.725 & - & -0.783 & -1.304 & -1.529 & -0.596 \\
\hline Holland & -1.815 & -2.171 & -0.626 & 1.273 & -0.692 & -1.275 & -1.922 & -1.327 & -1.821 \\
\hline Italy & -1.364 & -0.457 & -0.981 & -0.656 & -0.559 & - & -1.532 & -1.947 & -0.284 \\
\hline Norway & -1.036 & -0.840 & 0.307 & -0.234 & -2.000 & 0.946 & -0.494 & -0.937 & -0.078 \\
\hline Poland & 0.553 & 3.055 & -0.222 & 2.425 & -0.635 & -0.966 & -0.399 & -1.364 & -1.142 \\
\hline United Kingdom & -0.295 & -6.313 & -0.736 & -1.368 & 0.233 & -0.812 & - & -0.485 & -1.223 \\
\hline Russia & -1.847 & 0.954 & -0.941 & -0.613 & -0.788 & -1.746 & -2.062 & - & -1.520 \\
\hline Sweden & -0.364 & 2.767 & -1.594 & -0.430 & 0.995 & -0.394 & 0.132 & 0.376 & 0.215 \\
\hline Switzerland & -0.839 & 0.843 & -2.169 & 1.085 & -1.190 & -2.409 & 0.148 & -2.506 & -1.180 \\
\hline Rest of the World & -0.998 & -1.003 & 0.106 & -0.605 & -0.760 & -0.148 & -0.918 & 0.376 & -0.164 \\
\hline Average & -0.958 & -0.936 & -0.700 & -0.318 & -0.711 & -0.760 & -0.865 & -0.531 & -0.343 \\
\hline
\end{tabular}

Cerne, Lavras, v. 17, n. 1, p. 33-45, jan./mar. 2011 
Table 2 - Equations of total import demand for fiberboard panels.

Tabela 2 - Equações de demanda total de importação de painéis de fibra de madeira.

\begin{tabular}{lccccc}
\hline Importing country & Intercept & $\mathrm{P}_{\mathrm{i}}{ }^{1}$ coefficient & $\begin{array}{c}\text { Per capita GDP } \\
\text { coefficient }\end{array}$ & $\begin{array}{c}\text { Lagged dependent } \\
\text { variable coefficient }\end{array}$ & $\mathrm{R}^{2}$ \\
\hline Germany & $19.634(1.065)$ & $-1.301(-1.132)$ & $0.151(0.105)$ & $0.056(0.128)$ & 0.223 \\
Canada & $7.350(1.144)$ & $-1.053(-2.039)$ & $1.848(2.430)$ & $-0.602(-1.644)$ & 0.613 \\
China & $43.889(9.632)$ & $-2.277(-6.893)$ & $-1.946(-6.509)$ & $-0.138(-0.939)$ & 0.954 \\
United States & $-83.709(-1.262)$ & $-0.396(-0.421)$ & $9.427(1.492)$ & $-0.388(-1.119)$ & 0.342 \\
France & $-5.059(-0.458)$ & $-1.368(-1.794)$ & $2.274(1.548)$ & $0.316(1.089)$ & 0.422 \\
Italy & $-10.590(-1.678)$ & $-1.036(-2.804)$ & $2.379(2.663)$ & $0.488(2.351)$ & 0.842 \\
United Kingdom & $5.446(0.752)$ & $-1.177(-2.028)$ & $1.105(2.258)$ & $0.590(2.316)$ & 0.719 \\
Russia & $6.917(1.385)$ & $-1.340(-1.943)$ & $1.760(3.068)$ & $-0.100(-0.304)$ & 0.806 \\
Rest of the World & $-35.120(-2.256)$ & $-1.361(-1.156)$ & $7.575(3.091)$ & $-0.101(-0.337)$ & 0.890 \\
\hline
\end{tabular}

Values in brackets refer to Student's t-statistic.

- indicates presence of autocorrelation, as demonstrated by Durbin's h-statistic.

${ }^{1}$ Refers to price elasticities of total import demand for fiberboard panels.

${ }^{2}$ Refers to income elasticities of total import demand for fiberboard panels.

An analysis of the statistical significance of coefficients by Student's t-test revealed that five price elasticities were significant, at the $10 \%$ level or less, and five income elasticities were significant, at the $5 \%$ level or less.

The coefficient of the lagged dependent variable of Canada, Italy and United Kingdom was significant, at the $10 \%$ level or less, indicating that the demand for fiberboard panels in those countries does not adjust instantly, due to variations in import prices and levels of income.

The sign of price elasticities was negative in all equations, agreeing with descriptions in the theory of demand. Except for the United States, all price elasticities were higher than one, indicating that, in those countries, a change in the price of fiberboard panels, all other things being held constant, would cause more than proportional changes in demanded quantities, characterizing an elastic demand in relation to price.

As regards the United States, the value -0.396 for price elasticity indicates that total import demand for fiberboard panels is hardly sensitive to variations in price since, if product price increases by $10 \%$, all other things being held constant, the quantity imported by the country only drops by $3.96 \%$. It should be noted that the United States is the world's largest importer of fiberboard panels, accounting for about $14 \%$ of the global total sold in 2007. Therefore, it can be inferred that the United States will affect the price of this product according to its choice of supply source.
The sign of income elasticities of importing countries was positive, except for China, contradicting principles in the theory of demand.

Judging by the magnitude of most estimated coefficients (higher than one), it becomes evident that the total import demand for fiberboard panels from the countries being considered is very sensitive to variations in income, which characterizes an elastic demand for the product. A $10 \%$ increase in the per capita GDP of Canada, United States, France, Italy, United Kingdom, Russia and Rest of the World, all other things being held constant, causes a $18.48 \%, 94.27 \%, 22.74 \%, 23.79 \%, 11.05 \%$, $17.60 \%$ and $75.75 \%$ rise in demand respectively.

As regards Germany, demand proved inelastic with respect to income. The income elasticity value of 0.151 indicates that a $10 \%$ increase in the country's per capita income, all other things being held constant, only increases demand by $1.51 \%$.

Own-price and cross-price elasticities of demand for fiberboard panels differentiated by country of origin were obtained through formulas 8 and 9, computing average elasticities of substitution of model (12) (secondstage equations), price elasticities of total import demand for panels (first-stage equations), and ratios of spending from importing countries, as illustrated in Table 3.

According to Table 3 data, out of the total spending of Germany with fiberboard panels consumed in the 2004-2006 interval, $63.81 \%$ relates to panels produced

Cerne, Lavras, v. 17, n. 1, p. 33-45, jan./mar. 2011 
Table 3 - Ratio of spending on imports of fiberboard panels produced by relevant exporting countries, concerning the 2004-2006 period.

Tabela 3 - Proporção dos gastos com a importação de painéis de fibra de madeira produzido nos diversos países exportadores, referente ao periodo 2004-2006.

\begin{tabular}{|c|c|c|c|c|c|c|c|c|c|}
\hline \multirow{2}{*}{ Exporting countries } & \multicolumn{9}{|c|}{ Importing countries $^{1}$} \\
\hline & $\mathrm{AL}$ & CA & $\mathrm{CH}$ & EUA & FR & IT & $\mathrm{RE}$ & RU & $\mathrm{RDM}_{1}$ \\
\hline Austria & 0.05173 & 0.00172 & 0.00028 & 0.00042 & 0.03729 & 0.03838 & 0.01205 & 0.00575 & 0.01866 \\
\hline Belgium & 0.02007 & 0.01776 & 0.00056 & 0.01002 & 0.09706 & 0.01902 & 0.07331 & 0.01390 & 0.02945 \\
\hline Brazil & 0.00116 & 0.00440 & 0.00216 & 0.00939 & 0.00238 & 0.00287 & 0.00145 & 0.00079 & 0.00753 \\
\hline Canada & 0.00003 & 0.43095 & 0.00044 & 0.06228 & 0.00399 & 0.00008 & 0.00087 & 0.00105 & 0.00211 \\
\hline China & 0.00029 & 0.04175 & 0.91716 & 0.01170 & 0.00042 & 0.00329 & 0.00229 & 0.02153 & 0.03099 \\
\hline France & 0.03211 & 0.00317 & 0.00006 & 0.00289 & 0.30471 & 0.04380 & 0.01641 & 0.00639 & 0.03969 \\
\hline Germany & 0.63816 & 0.08180 & 0.00125 & 0.02713 & 0.08314 & 0.06705 & 0.07975 & 0.08488 & 0.13165 \\
\hline Italy & 0.00316 & 0.00025 & 0.00221 & 0.00039 & 0.00790 & 0.45908 & 0.00114 & 0.00476 & 0.01314 \\
\hline Holland & 0.01271 & 0.00010 & 0.00001 & 0.00021 & 0.00207 & 0.00968 & 0.00245 & 0.00015 & 0.00207 \\
\hline Norway & 0.00215 & 0.00022 & 0.00002 & 0.00016 & 0.00341 & 0.00499 & 0.00457 & 0.00083 & 0.00398 \\
\hline Poland & 0.02533 & 0.01392 & 0.00006 & 0.00110 & 0.00225 & 0.00995 & 0.00994 & 0.02192 & 0.02797 \\
\hline Russia & 0.00069 & 0.00004 & 0.00072 & 0.00001 & 0.00005 & 0.00013 & 0.00020 & 0.63272 & 0.01340 \\
\hline Spain & 0.00326 & 0.00092 & 0.00002 & 0.00853 & 0.02140 & 0.02385 & 0.03626 & 0.00225 & 0.02335 \\
\hline Sweden & 0.00136 & 0.00020 & 0.00030 & 0.00137 & 0.02016 & 0.00341 & 0.00821 & 0.00566 & 0.01259 \\
\hline Switzerland & 0.02156 & 0.00174 & 0.00217 & 0.00152 & 0.00532 & 0.00967 & 0.01237 & 0.00061 & 0.01245 \\
\hline United Kingdom & 0.00089 & 0.00003 & 0.00009 & 0.00016 & 0.00164 & 0.00011 & 0.28312 & 0.00011 & 0.00743 \\
\hline United States & 0.00017 & 0.09489 & 0.00057 & 0.68011 & 0.00262 & 0.00038 & 0.00427 & 0.00057 & 0.00831 \\
\hline Rest of the World 2 & 0.18517 & 0.30615 & 0.07192 & 0.18261 & 0.40421 & 0.30425 & 0.45132 & 0.19613 & 0.61523 \\
\hline
\end{tabular}

Source: FAO (2008).

${ }^{1}$ Importing countries: Germany (AL), Canada (CA), China (CH), United States (EUA), France (FR), Italy (IT), United Kingdom (RE), Russia (RU) and Rest of the World $\left(\mathrm{RDM}_{1}\right)$.

domestically, that is, within Germany. The remaining panels were bought from other countries in the following ratios: Austria 5.17\%, Belgium 2.00\%, United States $0.01 \%$, Italy $0.31 \%$, Sweden $0.13 \%$, France $3.21 \%$, Canada $0.003 \%$, Brazil $0.11 \%$, China $0.02 \%$, Holland $1.27 \%$, Norway $0.21 \%$, Poland $2.53 \%$, Russia $0.06 \%$, Spain $0.32 \%$, Switzerland $2.15 \%$, United Kingdom $0.08 \%$, and Rest of the World $18.51 \%$.

Own-price elasticities of import demand for fiberboard panels, as differentiated by country of origin, are provided in Table 4 . The demand was inelastic in all markets, except in the case of the United Kingdom, in which the countries grouped as Rest of the World $\left(\mathrm{RDM}_{2}\right)$ had an elastic demand.

Taking as an example the case of Germany as importer and Brazil as exporter, the value -0.9584 for ownprice elasticity of demand concerning Brazilian exports indicates that, if the price of Brazilian panels is subjected to a $10 \%$ increase, the demand from Germany for panels originating in Brazil drops by $9.584 \%$. It can be thus said that changes in the price of Brazilian fiberboard panels cause less than proportional changes in product quantities demanded by Germany.

Where the elasticity of substitution is smaller than the price elasticity of total import demand, as is the case with all markets considered here, a direct relationship is expected between the ratio of spending on panel imports and the own-price and cross-price elasticities. This can be demonstrated by comparing, for instance, the elasticities of Belgium and Russia in relation to the French market, where elasticities of substitution and price were 0.711 and -1.368 respectively. Belgium accounts for $9.706 \%$ of the total value imported by France and is its largest supplier of panels. For this reason, the French own-price $(-0.77477)$

Cerne, Lavras, v. 17, n. 1, p. 33-45, jan./mar. 2011 
Table 4 - Own-price elasticities $\left(\eta_{\mathrm{ijj}}\right)$ of import demand for fiberboard panels in relevant countries.

Tabela 4 - Elasticidades-preço diretas $\left(\eta_{i j i}\right)$ da demanda de importação de painel de fibra de madeira dos países considerados.

\begin{tabular}{|c|c|c|c|c|c|c|c|c|c|}
\hline \multirow{2}{*}{$\begin{array}{l}\text { Exporting } \\
\text { countries }\end{array}$} & \multicolumn{9}{|c|}{ Importing countries $^{1}$} \\
\hline & $\mathrm{AL}$ & $\mathrm{CA}$ & $\mathrm{CH}$ & EUA & FR & IT & $\mathrm{RE}$ & RU & $\mathrm{RDM}_{1}$ \\
\hline Austria & -0.975743 & -0.936202 & -0.700446 & -0.318032 & -0.735499 & -0.770594 & -0.868760 & -0.535650 & -0.361994 \\
\hline Belgium & -0.964884 & -0.938078 & -0.700876 & -0.318782 & -0.774768 & -0.765250 & -0.887873 & -0.542246 & -0.372975 \\
\hline Brazil & -0.958398 & -0.936514 & -0.703411 & -0.318733 & -0.712566 & -0.760791 & -0.865453 & -0.531636 & -0.350666 \\
\hline Canada & -0.958011 & - & -0.700687 & -0.322858 & -0.713622 & -0.760022 & -0.865272 & -0.531851 & -0.345148 \\
\hline China & -0.958101 & -0.940884 & - & -0.318912 & -0.711274 & -0.760909 & -0.865715 & -0.548416 & -0.374543 \\
\hline France & -0.969015 & -0.936371 & -0.700089 & -0.318225 & - & -0.772090 & -0.870121 & -0.536168 & -0.383403 \\
\hline Germany & - & -0.945570 & -0.701974 & -0.320116 & -0.765620 & -0.778507 & -0.889881 & -0.599670 & -0.477024 \\
\hline Italy & -0.959084 & -0.936029 & -0.703478 & -0.318031 & -0.716190 & - & -0.865357 & -0.534848 & -0.356376 \\
\hline Holland & -0.962361 & -0.936011 & -0.700021 & -0.318016 & -0.712358 & -0.762672 & -0.865764 & -0.531123 & -0.345108 \\
\hline Norway & -0.958739 & -0.936025 & -0.700027 & -0.318013 & -0.713242 & -0.761378 & -0.866426 & -0.531675 & -0.347056 \\
\hline Poland & -0.966690 & -0.937629 & -0.700102 & -0.318085 & -0.712480 & -0.762746 & -0.868102 & -0.548734 & -0.371475 \\
\hline Russia & -0.958235 & -0.936005 & -0.701135 & -0.318001 & -0.711031 & -0.760036 & -0.865061 & - & -0.356643 \\
\hline Spain & -0.959118 & -0.936108 & -0.700036 & -0.318666 & -0.725062 & -0.766582 & -0.876313 & -0.532817 & -0.366765 \\
\hline Sweden & -0.958465 & -0.936024 & -0.700467 & -0.318107 & -0.724244 & -0.760942 & -0.867561 & -0.535579 & -0.355817 \\
\hline Switzerland & -0.965396 & -0.936203 & -0.703430 & -0.318119 & -0.714493 & -0.762669 & -0.868860 & -0.531493 & -0.355673 \\
\hline United Kingdom & -0.958305 & -0.936003 & -0.700136 & -0.318012 & -0.712075 & -0.760031 & - & -0.531087 & -0.350562 \\
\hline United States & -0.958057 & -0.947102 & -0.700903 & - & -0.712718 & -0.760104 & -0.866334 & -0.531463 & -0.351462 \\
\hline $\mathrm{RDM}_{2}$ & -1.021514 & -0.971820 & -0.813416 & -0.332244 & -0.976567 & -0.843973 & -1.005812 & -0.689673 & - \\
\hline
\end{tabular}

${ }^{1}$ Importing countries: Germany (AL), Canada (CA), China (CH), United States (EUA), France (FR), Italy (IT), United Kingdom (RE), Russia (RU) and Rest of the World (RDM $)$.

${ }^{2}$ Exporting country: Rest of the World $\left(\mathrm{RDM}_{2}\right)$.

and cross-price (-0.06377) elasticities are the highest. Russia, on the other hand, has the weakest participation in the French market $(0.0005 \%)$, with own-price $(-0.71103)$ and cross-price $(-0.0003)$ elasticities being the lowest in the French market.

Where the elasticity of substitution is greater than the price elasticity of total import demand, though not the case in this study, an inverse relationship would be expected between the ratio of spending on imports and the own-price elasticity, while a direct relationship would be expected between the ratio and the cross-price elasticity.

Cross-price elasticities of demand for fiberboard panels differentiated by country of origin are illustrated in Table 5. Negative values indicate a certain complementarity in the use of fiberboard panels in relevant markets. It is thus expected that an increase in the price of panels from a given country, all other things being held constant, will reduce the demand for panels offered by a competitor country. Taking the case of China as importer as an example, the value -0.0034 of cross-price elasticity of Brazil in that market indicates that, should there be an increase of $10 \%$ in the price of Brazilian fiberboard panels, all other things being held constant, the demand from China for panels exported by competitor countries drops by $0.034 \%$.

An analysis of the formula used to calculate crossprice elasticities $\left(\eta_{i j h}=S_{i h} \cdot \sigma_{i}+S_{i h} \cdot \eta_{i}\right)$ allows understanding the negative sign of values. The first term in the formula $\left(S_{i h}, \sigma_{i}\right)$ refers to the substitution effect whereby a shift occurs from country $j$ to country $i$, due to a change in price of panels offered by a competitor country $(h)$. Taking, for instance, China $(i)$ as importing country and Brazil (h) as exporting country, the substitution effect will be 0.001512 . The second term in the formula $\left(S_{i h} \cdot \eta_{i}\right)$ refers to the reduction effect whereby the total quantity of panels imported by China drops, the value being -0.004918 .

Cerne, Lavras, v. 17, n. 1, p. 33-45, jan./mar. 2011 
Table 5 - Cross-price elasticities $\left(\eta_{\mathrm{ijh}}\right)$ of import demand for fiberboard panels in relevant countries.

Tabela 5 - Elasticidades-preço cruzadas $\left(\eta_{i j h}\right)$, da demanda de importação de painel de fibra de madeira dos países considerados.

\begin{tabular}{|c|c|c|c|c|c|c|c|c|c|}
\hline \multirow{2}{*}{$\begin{array}{l}\text { Exporting } \\
\text { countries }\end{array}$} & \multicolumn{9}{|c|}{ Importing countries $^{1}$} \\
\hline & $\mathrm{AL}$ & $\mathrm{CA}$ & $\mathrm{CH}$ & EUA & FR & IT & $\mathrm{RE}$ & RU & $\mathrm{RDM}_{1}$ \\
\hline Austria & -0.017743 & -0.000201 & -0.000442 & -0.000033 & -0.024500 & -0.010593 & -0.003760 & -0.004652 & -0.018996 \\
\hline Belgium & -0.006884 & -0.002078 & -0.000883 & -0.000782 & -0.063768 & -0.005250 & -0.022873 & -0.011245 & -0.029980 \\
\hline Brazil & -0.000398 & -0.000515 & -0.003406 & -0.000732 & -0.001564 & -0.000792 & -0.000452 & -0.000639 & -0.007666 \\
\hline Canada & -0.000010 & - & -0.000694 & -0.004858 & -0.002621 & -0.000022 & -0.000271 & -0.000849 & -0.002148 \\
\hline China & -0.000099 & -0.004885 & - & -0.000913 & -0.000276 & -0.000908 & -0.000714 & -0.017418 & -0.031548 \\
\hline France & -0.011014 & -0.000371 & -0.000095 & -0.000225 & - & -0.012089 & -0.005120 & -0.005170 & -0.040404 \\
\hline Germany & - & -0.009571 & -0.001971 & -0.002116 & -0.054623 & -0.018506 & -0.024882 & -0.068668 & -0.134020 \\
\hline Italy & -0.001084 & -0.000029 & -0.003485 & -0.000030 & & - & -0.000356 & & \\
\hline Holland & -0.004360 & -0.000012 & -0.000016 & -0.000016 & -0.001360 & -0.002672 & -0.000764 & -0.000121 & -0.002107 \\
\hline Norway & -0.000737 & -0.000026 & -0.000032 & -0.000012 & -0.002240 & -0.001377 & -0.001426 & -0.000671 & -0.004052 \\
\hline Poland & -0.008688 & -0.001629 & -0.000095 & -0.000086 & -0.001478 & -0.002746 & -0.003101 & -0.017733 & -0.028473 \\
\hline Russia & -0.000237 & -0.000005 & -0.001135 & -0.000001 & -0.000033 & -0.000036 & -0.000062 & - & -0.013641 \\
\hline Spain & -0.001118 & -0.000108 & -0.000032 & -0.000665 & -0.014060 & -0.006583 & -0.011313 & -0.001820 & -0.023770 \\
\hline Sweden & -0.000466 & -0.000023 & -0.000473 & -0.000107 & -0.013245 & -0.000941 & -0.002562 & -0.004579 & -0.012817 \\
\hline Switzerland & -0.007395 & -0.000204 & -0.003422 & -0.000119 & -0.003495 & -0.002669 & -0.003859 & -0.000493 & -0.012674 \\
\hline United Kingdom & -0.000305 & -0.000004 & -0.000142 & -0.000012 & -0.001077 & -0.000030 & - & -0.000089 & -0.007564 \\
\hline United States & -0.000058 & -0.011102 & -0.000899 & - & -0.001721 & -0.000105 & -0.001332 & -0.000461 & -0.008460 \\
\hline $\mathrm{RDM}_{2}$ & -0.063513 & -0.035820 & -0.113418 & -0.014244 & -0.265566 & -0.083973 & -0.140812 & -0.158669 & -0.96931 \\
\hline
\end{tabular}

${ }^{1}$ Importing countries: Germany (AL), Canada (CA), China (CH), United States (EUA), France (FR), Italy (IT), United Kingdom (RE), Russia (RU) and Rest of the World $\left(\mathrm{RDM}_{1}\right)$.

Thus, a $10 \%$ increase in the price of Brazilian panels, all other things being held constant, reduces by $0.04918 \%$ the total quantity China imports from Brazil, there being thus a decline in the Chinese market in the same proportion.

The import substitution effect indicates that $0.01512 \%$ of the panel total China was importing from Brazil should shift to being bought from a competitor country. Yet the Chinese market shrank at a higher rate $(0.004918)$ than the rate of imports substitution (0.001512), causing a drop in the rate of sales from the competitor country(ies) to China, of 0.0034 . This explains the magnitude and negative sign of cross-price elasticity of Brazil with respect to China.

It should be noted that the net effect is clearly dependent on the magnitude of the elasticity of substitution $\left(\sigma_{i}\right)$ and of the price elasticity of total import demand for panels $\left(\eta_{i}\right)$. As in this study $\sigma_{i}$ was lower than $\eta_{i}$ in all markets, the cross-price elasticity was also negative in all of them. Where, in a given market, there is an increase in the price of panels from exporting country $h$, all other things being held constant, the decrease in the total quantity of panels imported by that market will be greater than the increase in the quantity imported, induced by the substitution of panels from country $h$ for panels from country $j$. Substitution effects and market reduction (or expansion) effects for all markets are illustrated in Table 6.

In the formula used for calculating own-price elasticities $\left(\eta_{i j j}=-\left(1-S_{i j}\right) \sigma_{i}+S_{i j} \eta_{i}\right)$, import substitution effect is given by the first term and market expansion or reduction effect is given by the second term. Values calculated for all importing countries are provided in Table 7. Taking the Canadian market, for instance, the United States ranked first as largest exporter, accounting for $9.49 \%$ of the total imported (Table 3). Therefore, the import substitution effect and market reduction (or expansion) effect are equal to -0.84718 and -0.09992 respectively.

Cerne, Lavras, v. 17, n. 1, p. 33-45, jan./mar. 2011 
Table 6 - Decomposition of cross-price elasticities of import demand for fiberboard panels of importing countries into import substitution (S) and market expansion (E/R) effects.

Tabela 6 - Decomposição das elasticidades-preço cruzadas da demanda de importação de painéis de fibra de madeira dos países importadores em efeitos substituição de importações $(S)$ e expansão $(E / R)$ do mercado.

\begin{tabular}{|c|c|c|c|c|c|c|c|c|c|c|}
\hline \multirow{2}{*}{$\begin{array}{l}\text { Exporting } \\
\text { countries }\end{array}$} & \multirow{2}{*}{ Effect } & \multicolumn{9}{|c|}{ Importing countries } \\
\hline & & $\mathrm{AL}$ & $\mathrm{CA}$ & $\mathrm{CH}$ & EUA & FR & IT & $\mathrm{RE}$ & RU & $\mathrm{RDM}_{1}$ \\
\hline \multirow{2}{*}{ Austria } & $S$ & 0.049557 & 0.001610 & 0.000196 & 0.000134 & 0.026513 & 0.029169 & 0.010423 & 0.003053 & 0.006400 \\
\hline & $\mathrm{E} / \mathrm{R}$ & -0.067301 & -0.001811 & -0.000638 & -0.000166 & -0.051013 & -0.039762 & -0.014183 & -0.007705 & -0.025394 \\
\hline \multirow{2}{*}{ Belgium } & $\mathrm{S}$ & .019227 & 0.016623 & 0.000392 & 0.003186 & 0.069010 & 0.014455 & 0.063413 & 0.007381 & 0.010100 \\
\hline & $E / R$ & -0.026111 & -0.018701 & -0.001275 & -0.003968 & -0.132778 & -0.019705 & -0.086286 & -0.018626 & -0.040075 \\
\hline \multirow{2}{*}{ Brazil } & S & 0.001111 & 0.004118 & 0.001512 & 0.002986 & 0.001692 & 0.002181 & 0.001254 & 0.000419 & 0.002583 \\
\hline & $E / R$ & -0.001509 & -0.004633 & -0.004918 & -0.003718 & -0.003256 & -0.002973 & -0.001707 & -0.001059 & -0.010248 \\
\hline \multirow{2}{*}{ Canada } & $\mathrm{S}$ & 0.000029 & - & 0.000308 & 0.019805 & 0.002837 & 0.000061 & 0.000753 & 0.000558 & 0.000724 \\
\hline & $\mathrm{E} / \mathrm{R}$ & -0.000039 & - & -0.001002 & -0.024663 & -0.005458 & -0.000083 & -0.001024 & -0.001407 & -0.002872 \\
\hline \multirow{2}{*}{ China } & $\mathrm{S}$ & 0.000278 & 0.039078 & - & 0.003721 & 0.000299 & 0.002500 & 0.001981 & 0.011432 & 0.010628 \\
\hline & $\mathrm{E} / \mathrm{R}$ & -0.000377 & -0.043963 & - & -0.004633 & -0.000575 & -0.003408 & -0.002695 & -0.028850 & -0.042171 \\
\hline \multirow{2}{*}{ France } & $\mathrm{S}$ & & 0.002967 & 0.000042 & 0.000919 & - & 0.033288 & 0.014195 & & 0.013613 \\
\hline & $\mathrm{E} / \mathrm{R}$ & -0.041775 & & -0.000137 & -0.001144 & - & & & & \\
\hline \multirow{2}{*}{ Germany } & $\mathrm{S}$ & - & 0.076565 & 0.000875 & 0.008627 & & 0.050958 & 0.068984 & 0.045071 & 0.045158 \\
\hline & $\mathrm{E} / \mathrm{R}$ & - & -0.086135 & -0.002846 & -0.010743 & -0.113736 & -0.069464 & -0.093866 & -0.113739 & -0.179182 \\
\hline \multirow{2}{*}{ Italy } & $\mathrm{S}$ & 0.003027 & 0.000234 & 0.001547 & 0.000124 & 0.005617 & - & 0.000986 & 0.002528 & 0.004507 \\
\hline & $E / R$ & -0.004111 & -0.000263 & -0.005032 & -0.000154 & -0.010807 & - & -0.001342 & -0.006378 & -0.017883 \\
\hline \multirow{2}{*}{ Holland } & $\mathrm{S}$ & 0.012176 & 0.000094 & 0.000007 & 0.000067 & 0.001472 & 0.007357 & 0.002119 & 0.000080 & 0.000710 \\
\hline & $\mathrm{E} / \mathrm{R}$ & -0.016536 & -0.000105 & -0.000023 & -0.000083 & -0.002832 & -0.010028 & -0.002884 & -0.000201 & -0.002819 \\
\hline \multirow{2}{*}{ Norway } & $\mathrm{S}$ & 0.002060 & 0.000206 & 0.000014 & 0.000051 & 0.002425 & 0.003792 & 0.003953 & 0.000441 & 0.001367 \\
\hline & $\mathrm{E} / \mathrm{R}$ & -0.002797 & -0.000232 & -0.000046 & -0.000063 & -0.004665 & -0.005170 & -0.005379 & -0.001112 & -0.005423 \\
\hline \multirow{2}{*}{$\mathrm{Po}$} & $\mathrm{S}$ & 0.024266 & 0.013029 & 0.000042 & 0.000350 & & & & 0.011640 & 0.009594 \\
\hline & $\mathrm{E} / \mathrm{R}$ & -0.032954 & -0.014658 & -0.000137 & -0.000436 & & & -0.011699 & -0.029373 & -0.038069 \\
\hline \multirow{2}{*}{ Russia } & $\mathrm{S}$ & 0.000661 & 0.000037 & 0.000504 & 0.000003 & 0.000036 & 0.000099 & 0.000173 & - & 0.004597 \\
\hline & $\mathrm{E} / \mathrm{R}$ & -0.000898 & -0.000042 & -0.001639 & -0.000004 & -0.000068 & -0.000135 & -0.000235 & - & -0.018239 \\
\hline \multirow{2}{*}{ Spain } & $\mathrm{S}$ & 0.003123 & 0.000861 & 0.000014 & 0.002617 & 0.015215 & 0.018126 & 0.031365 & 0.001195 & 0.008007 \\
\hline & $\mathrm{E} / \mathrm{R}$ & -0.004241 & -0.000969 & -0.000046 & -0.003259 & -0.029275 & -0.024709 & -0.042678 & -0.003015 & -0.031773 \\
\hline \multirow{2}{*}{ Sweden } & $\mathrm{S}$ & 0.001303 & 0.000187 & 0.000210 & 0.000436 & 0.014334 & 0.002592 & 0.007102 & 0.003005 & 0.004318 \\
\hline & $\mathrm{E} / \mathrm{R}$ & -0.001769 & -0.000211 & -0.000683 & -0.000543 & -0.027579 & -0.003533 & -0.009663 & -0.007584 & -0.017135 \\
\hline \multirow{2}{*}{ Switzerland } & S & 0.020654 & 0.001629 & 0.001519 & 0.000483 & 0.003783 & 0.007349 & 0.010700 & 0.000324 & 0.004270 \\
\hline & $\mathrm{E} / \mathrm{R}$ & -0.028050 & -0.001832 & -0.004941 & -0.000602 & -0.007278 & -0.010018 & -0.014559 & -0.000817 & -0.016944 \\
\hline \multirow{2}{*}{$\begin{array}{l}\text { United } \\
\text { Kingdom }\end{array}$} & $\mathrm{S}$ & 0.008526 & 0.000028 & 0.000063 & 0.000051 & 0.001166 & 0.000084 & - & 0.000058 & 0.002548 \\
\hline & $E / R$ & -0.011579 & -0.000032 & -0.000205 & -0.000063 & -0.002244 & -0.000114 & - & -0.000147 & -0.010110 \\
\hline \multirow{2}{*}{ EUA } & S & 0.000163 & 0.088817 & 0.000399 & - & 0.001863 & 0.000289 & 0.003694 & 0.000303 & 0.002851 \\
\hline & $E / R$ & -0.000221 & -0.099919 & -0.001298 & - & -0.003584 & -0.000394 & -0.005026 & -0.000764 & -0.011313 \\
\hline \multirow{2}{*}{$\begin{array}{l}\text { Rest of the } \\
\text { World } 2\end{array}$} & $\mathrm{~S}$ & 0.177393 & 0.286556 & 0.050344 & 0.058070 & 0.287393 & 0.231230 & 0.390392 & 0.104145 & 0.211025 \\
\hline & $\mathrm{E} / \mathrm{R}$ & -0.240906 & -0.322376 & -0.163762 & -0.072314 & -0.552959 & -0.315203 & -0.531204 & -0.262814 & -0.837334 \\
\hline
\end{tabular}

Cerne, Lavras, v. 17, n. 1, p. 33-45, jan./mar. 2011 
Table 7 - Decomposition of own-price elasticities of import demand for fiberboard panels of importing countries into imports substitution (S) and market expansion (E/R) effects.

Tabela 7 - Decomposição das elasticidades-preço diretas da demanda de importação de painéis de fibra de madeira dos países importadores em efeitos substituição de importações $(S)$ e expansão (E/R) do mercado.

\begin{tabular}{|c|c|c|c|c|c|c|c|c|c|c|}
\hline \multirow{2}{*}{$\begin{array}{l}\text { Exporting } \\
\text { countries }\end{array}$} & \multirow{2}{*}{ Effect } & \multicolumn{9}{|c|}{ Importing countries } \\
\hline & & $\mathrm{AL}$ & $\mathrm{CA}$ & $\mathrm{CH}$ & EUA & FR & IT & $\mathrm{RE}$ & RU & $\mathrm{RDM}_{1}$ \\
\hline \multirow{2}{*}{ Austria } & $\mathrm{S}$ & -0.908443 & -0.934390 & -0.699804 & -0.317866 & -0.684487 & -0.730831 & -0.854577 & -0.527947 & -0.336600 \\
\hline & $\mathrm{E} / \mathrm{R}$ & -0.067301 & -0.001811 & -0.000638 & -0.000166 & -0.051013 & -0.039762 & -0.014183 & -0.007705 & -0.025394 \\
\hline \multirow{2}{*}{ Belgium } & $\mathrm{S}$ & -0.938773 & -0.919377 & -0.699608 & -0.314814 & -0.641990 & -0.745545 & -0.801587 & -0.523619 & -0.332900 \\
\hline & $\mathrm{E} / \mathrm{R}$ & $-0,026111$ & $-0,018701$ & $-0,001275$ & $-0,003968$ & $-0,132778$ & $-0,019705$ & $-0,086286$ & $-0,018626$ & $-0,040075$ \\
\hline \multirow{2}{*}{ Brazil } & $\mathrm{S}$ & $-0,956889$ & $-0,931882$ & $-0,698488$ & $-0,315014$ & $-0,709308$ & $-0,757819$ & $-0,863746$ & $-0,530581$ & $-0,340417$ \\
\hline & $\mathrm{E} / \mathrm{R}$ & $-0,001509$ & $-0,004633$ & $-0,004918$ & $-0,003718$ & $-0,003256$ & $-0,002973$ & $-0,001707$ & $-0,001059$ & $-0,010248$ \\
\hline \multirow{2}{*}{ Canada } & $\mathrm{S}$ & $-0,957971$ & - & $-0,699692$ & $-0,298195$ & $-0,708163$ & $-0,759939$ & $-0,864247$ & $-0,530442$ & $-0,342276$ \\
\hline & $\mathrm{E} / \mathrm{R}$ & $-0,000039$ & - & $-0,001002$ & $-0,024663$ & $-0,005458$ & $-0,000083$ & $-0,001024$ & $-0,001407$ & $-0,002872$ \\
\hline \multirow{2}{*}{ China } & $\mathrm{S}$ & $-0,957722$ & $-0,896922$ & - & $-0,314279$ & $-0,710701$ & $-0,757500$ & $-0,863019$ & $-0,519568$ & $-0,332372$ \\
\hline & $\mathrm{E} / \mathrm{R}$ & $-0,000377$ & $-0,043963$ & - & $-0,004633$ & & & $-0,002695$ & & $-0,042171$ \\
\hline \multirow{2}{*}{ France } & $\mathrm{S}$ & & $-0,933033$ & $-0,699958$ & $-0,317081$ & - & & $-0,850805$ & & \\
\hline & $\mathrm{E} / \mathrm{R}$ & -0.041775 & -0.003338 & -0.000137 & -0.001144 & - & -0.045377 & -0.019315 & -0.008563 & -0.054016 \\
\hline \multirow{2}{*}{ Germany } & $\mathrm{S}$ & -0.958000 & -0.859435 & -0.699125 & -0.309373 & -0.651887 & -0.709042 & -0.796016 & -0.485929 & -0.297842 \\
\hline & $\mathrm{E} / \mathrm{R}$ & - & -0.086135 & -0.002846 & -0.010743 & -0.113736 & -0.069464 & -0.093866 & -0.113739 & -0.179182 \\
\hline \multirow{2}{*}{ Italy } & $\mathrm{S}$ & -0.954973 & -0.935766 & -0.698453 & -0.317876 & -0.705383 & - & -0.864014 & -0.528472 & -0.338493 \\
\hline & $\mathrm{E} / \mathrm{R}$ & -0.004111 & -0.000263 & -0.005032 & -0.000154 & -0.010807 & - & -0.001342 & -0.006378 & -0.017883 \\
\hline \multirow{2}{*}{ Holland } & $\mathrm{S}$ & -0.945824 & -0.935906 & -0.699993 & -0.317933 & -0.709528 & -0.752643 & -0.862881 & -0.530920 & -0.342290 \\
\hline & $\mathrm{E} / \mathrm{R}$ & -0.016536 & -0.000105 & -0.000023 & -0.000083 & -0.002832 & -0.010028 & -0.002884 & -0.000201 & -0.002819 \\
\hline \multirow{2}{*}{ Norway } & $\mathrm{S}$ & & & & & & & & & \\
\hline & $\mathrm{E} / \mathrm{R}$ & -0.002797 & -0.000232 & -0.000046 & -0.000063 & & & & & \\
\hline \multirow{2}{*}{ Poland } & $\mathrm{S}$ & -0.933734 & -0.922971 & -0.699958 & -0.317650 & & -0.752438 & -0.856402 & -0.519360 & -0.333406 \\
\hline & $\mathrm{E} / \mathrm{R}$ & -0.032954 & -0.014658 & -0.000137 & -0.000436 & -0.003078 & -0.010308 & -0.011699 & -0.029373 & -0.038069 \\
\hline \multirow{2}{*}{ Russia } & S & -0.957339 & -0.935963 & -0.699496 & -0.317997 & & -0.759901 & -0.864827 & - & -0.338403 \\
\hline & $\mathrm{E} / \mathrm{R}$ & -0.000898 & -0.000042 & -0.001639 & -0.000004 & -0.000068 & -0.000135 & -0.000235 & - & -0.018239 \\
\hline \multirow{2}{*}{ Spain } & $\mathrm{S}$ & -0.954877 & -0.935139 & -0.699986 & -0.315383 & -0.695785 & -0.741874 & -0.833635 & -0.529805 & -0.334993 \\
\hline & $\mathrm{E} / \mathrm{R}$ & -0.004241 & -0.000969 & -0.000046 & -0.003259 & -0.029275 & -0.024709 & -0.042678 & -0.003015 & -0.031773 \\
\hline \multirow{2}{*}{ Sweden } & $\mathrm{S}$ & -0.956697 & -0.935813 & -0.699790 & -0.317564 & -0.696666 & -0.757408 & -0.857898 & -0.527995 & -0.338682 \\
\hline & $\mathrm{E} / \mathrm{R}$ & -0.001769 & -0.000211 & -0.000683 & -0.000543 & -0.027579 & -0.003533 & -0.009663 & -0.007584 & -0.017135 \\
\hline \multirow{2}{*}{ Switzerland } & S & -0.937346 & -0.934371 & -0.698481 & -0.317517 & -0.707217 & -0.752651 & -0.854300 & -0.530676 & -0.338730 \\
\hline & $\mathrm{E} / \mathrm{R}$ & -0.028050 & -0.001832 & -0.004941 & -0.000602 & -0.007278 & -0.010018 & -0.014559 & -0.000817 & -0.016944 \\
\hline \multirow{2}{*}{$\begin{array}{l}\text { United } \\
\text { Kingdom }\end{array}$} & $\mathrm{S}$ & -0.949474 & -0.935972 & -0.699937 & -0.317949 & -0.709834 & -0.759916 & - & -0.530942 & -0.340452 \\
\hline & $\mathrm{E} / \mathrm{R}$ & -0.011579 & -0.000032 & -0.000205 & -0.000063 & -0.002244 & -0.000114 & - & -0.000147 & -0.010110 \\
\hline \multirow{2}{*}{ EUA } & $\mathrm{S}$ & -0.957837 & -0.847183 & -0.699601 & - & -0.709137 & -0.759711 & -0.861306 & -0.530697 & -0.340149 \\
\hline & $\mathrm{E} / \mathrm{R}$ & -0.000221 & -0.099919 & -0.001298 & - & -0.003584 & -0.000394 & -0.005026 & -0.000764 & -0.011313 \\
\hline \multirow{2}{*}{$\begin{array}{l}\text { Rest of the } \\
\text { World } 2\end{array}$} & $\mathrm{~S}$ & -0.780607 & -0.649444 & -0.649656 & -0.259930 & -0.423607 & -0.528770 & -0.474608 & -0.426855 & -0.131975 \\
\hline & $\mathrm{E} / \mathrm{R}$ & -0.240906 & -0.322376 & -0.163762 & -0.072314 & -0.552959 & -0.315203 & -0.531204 & -0.262814 & -0.837334 \\
\hline
\end{tabular}


A $10 \%$ increase in the price of panels offered by the United States, all other things being held constant, causes a $0.9992 \%$ reduction in imports by Canada, by virtue of the reduction in the total quantity of panels bought by Canada (market reduction effect). And $8.4718 \%$ of the total volume of panels Canada was importing from the United States is now going to be imported from the competitor country(ies) (product substitution effect). The resulting effect is a $9.471 \%$ decline in panel sales from United States into Canada, explaining the sign and magnitude of the price elasticity of the United States with respect to the Canadian market $(-0.9471)$.

Considering the case of the United Kingdom, which is the country showing the weakest participation in the total value of panels imported by the Canadian market $(0.0003 \%)$, a $10 \%$ increase in the price of panels there, all other things being held constant, will cause only a $0.00032 \%$ drop in the total imported by Canada. A greater impact will be created by the substitution of panels from the United Kingdom for panels from other countries, in other words, $9.3597 \%$ of panels Canada imports from the United Kingdom will be bought from other sources. The result is a $9.36 \%$ drop in panel sales from United Kingdom into Canada, explaining the sign and magnitude of the price elasticity of the United Kingdom with respect to the Canadian market.

\section{CONCLUSIONS}

In Germany, Canada, China, France, Italy, United Kingdom and China, the demand was price elastic, while in the United States the demand was price inelastic, suggesting that, given its large participation in the international market as buyer of fiberboard panels, the United States may affect prices depending on its choice of supply source.

Except in Germany and in the United States, price and income elasticities in the remaining importing countries were higher than one, suggesting that in such markets fiberboard panels can be considered a superior good.

In Germany, China and United Kingdom, the total import demand for fiberboard panels was more sensitive to variations in price than in income, while in the remaining importing countries the reverse happened.

The own-price elasticity of demand for fiberboard panels, distinguished by country of origin, was higher than one in almost all markets, except in Germany and in the United Kingdom.

The negative cross-price elasticity values suggest that fiberboard panels imported from other exporting countries are complementary products.

\section{ACKNOWLEDGMENTS}

The authors wish to thank the National Council for Scientific and Technological Development (CNPq) for granting the scholarship to the second author and for providing financial support to the first author by means of the Edital Universal.

\section{REFERENCES}

ABBOTT, P. C.; PAARLBERG, P. L. Modeling the impact of the 1980 grain embargo. In: UNITED STATES OF AMERICA. Department of Agriculture. Embargoes, surplus disposal and U. S. agriculture. Washington, 1986. chap. 11, p. 45-63. (Agricultural Economic Report, 64).

ARMINGTON, P. S. The geographic pattern of trade and the effects price changes. International Monetary Fund Staff Papers, Washington, v. 16, p. 179-199, Aug. 1969a.

ARMINGTON, P. S. A theory of demand for products distringuished by place of production. International Monetary Fund Staff Papers, Washington, v. 16, p. 159178, Aug. 1969b.

BABULA, R. A. An Armington model of U. S. cotton exports. The Journal of Agricultural Ecnomics Research, London, v. 39, n. 4, p. 12-22, Apr. 1987.

BALL, R. J. (Ed.). The international linkage of national economics models. New York: North-Holland, 1973. 246 p.

BARROS, G. S. C. Economia da comercialização agrícola. Piracicaba: FEALQ, 1987. 306 p.

CHOU, J. J.; BUONGIORNO, J. United States demand for hardwood plywood imports by country of origen. Forest Science, Bethesda, v. 19, n. 2, p. 225-237, Feb. 1983.

CRUZ, E. S. Análise do comércio mundial de celulose e papel. 2001. 145 p. Dissertação (Mestrado em Floresta de Produção) - Universidade Federal de Lavras, Lavras, 2001.

FIGUEROA, E. E.; WEBB, A. An analysis of the U. S. grain embargo using a quarterly Armington: type model. In: UNITED STATE. Department of Agriculture. Embargoes, surplus disposal, and U. S. agriculture. Washington, 1986. chap. 12, p. 23-41. (USADA. Agricultural Economic Report, 564). 
FOOD AND AGRICULTURE ORGANIZATION. Base de dados FAOSTAT. Disponível em: <http://apps.fao.org>. Acesso em: 17 nov. 2008.

GALLANT, A. R.; GOEBEL, J. J. Nonlinear regression with autoregressive errors. Journal of the American Statistical Association, Washington, v. 71, n. 365, p. 961-967, Mar. 1976.

GOLDSTEIN, M.; KHAN, M. S. Large versus small price changes and the demannd for imports. International Monetary Fund Staff Papers, Washington, v. 23, n. 1, p. 200-225, Mar. 1976.

GRENNES, T.; JOHNSON, P. R.; THURSBY, M. The economes of world grain trade. Englewood Cliffs: Praeger, 1979. $129 \mathrm{p}$.

JOHNSON, P. R.; GRENNES, T.; THURSBY, M. Trade models with differentiated producs. American Journal of Agricultural Economics, Saint Paul, v. 61, p. 120-127, June 1979.

KHAN, M. S. Import and export demand in developing countries. Internacional Monetary Fund Staff Papers, Washington, v. 21, n. 4, p. 678-693, Nov. 1974.

OLIVEIRA, A. D. Análise das possíveis mudanças comerciais e estruturais do mercado internacional de celulose. 1995. 131 f. Tese (Doutorado em Ciências Florestais) - Universidade Federal de Viçosa, Viçosa, 1995.

OLIVEIRA, A. D.; SILVA, O. M.; REZENDE, J. L. P. Importação de celulose: demandas diferenciadas por local de origem. Nova Economia, Belo Horizonte, v. 6, n. 1, p. 165194, jul. 1996.
PENSON, J.; BABULA, R. Japanese monetary policies and U. S. agricultural exports. Journal of Agricultural Economics Research, London, v. 40, n. 1, p. 11-18, May 1998.

RIBEIRO, I. S. A. Análise do mercado internacional de compensado. 2003. 177 p. Dissertação (Mestrado em Ciências Florestais) - Universidade Federal de Lavras, Lavras, 2003.

SARRIS, A. H. European community enlargement and world trade in fruits an vegetables. American Journal of Agricultural Economics, Lexington, v. 65, n. 2, p. 235-246, May 1983.

SILVA, M. J. Selo Verde pode virar barreira não-tarifária. O Papel, São Paulo, v. 54, n. 9, p. 14-16, set. 1993.

SILVA, O. M. The international market for frozen concentrated orange juice: prospects for Brazil. 1990. $137 \mathrm{f}$. Thesis (Ph.D. in Economy) - North Carolina State University, Raleigh, 1990.

TURNOVISKY, S. J. International trading relationships for a small country: the case of New Zealand. Canadian Journal of Economics, Toronto, v. 1, n. 4, p. 772-790, Nov. 1968.

WILSON, J. F.; TAKACS, W. E. Differential responses to price and exchange rate influences in the foreign trade of selected industrial countries. Reviews Economic Studies, Bristol, v. 61, n. 2, p. 267-279, May 1979.

YADAV, G. A quarterly model of the Canadian demand for imports 1956-72. Canadian Journal of Economics, Toronto, v. 8, n. 3, p. 410-421, Aug. 1975. 